\title{
The Effectiveness of the Learning Module Cooperative Learning Student Facilitator and Explaining
}

\author{
Ramadhani Rahmatullah \\ Program Studi Magister Teknik Sipil, Fakultas Teknik, Universitas Negeri Padang \\ e-mail: ramadhanirahmatullah@rocketmail.com
} Syahril
Program Studi Magister Teknik Sipil, Fakultas Teknik, Universitas Negeri Padang
e-mail: syahrilunp@gmail.com

Rijal Abdullah

Program Studi Magister Teknik Sipil, Fakultas Teknik, Universitas Negeri Padang e-mail: rijalabdullah@gmail.com

\section{A R T I C L E I N F O \\ Article history: \\ 25 December 2020 \\ Received in revised form \\ 01 January 2021 \\ Accepted 25 January 2021 \\ Available online 03 February 2021

\begin{tabular}{l}
\hline Kata Kunci: \\
Cooperative Learning, \\
Student Facilitator and \\
Explaining \\
Keywords: \\
Cooperative Learning, \\
Student Facilitator and \\
Explaining
\end{tabular}

\begin{abstract}
A B S T R A K
Rendahnya pemahaman siswa yang berdampak terhadap rendahnya hasil belajar siswa pada mata pelajaran yang disebabkan orientasi pembelajaran terpusat kepada guru, siswa belum dapat belajar secara mandiri dan hanya mengandalkan penjelasan materi dari guru, dan bahan ajar yang tersedia belum dapat memfasilitasi siswa untuk belajar secara mandiri dan tuntas. Menjadi alasan penelitian yang bertujuan penelitian untuk menganalisis efektivitas modul pembelajaran Cooperative Learning Tipe Student Facilitator and Explaining. Penelitian menggunakan metode penelitian dan pengembangan (Research and Development / R\&D) dengan menggunakan model pengembangan Four-D (4D). Metode pengumpulan data yang digunakan adalah angket, dan tes. Metode analisis dilakukan dengan analisis deskriptif dan infernsial dengan uji t. Hasil yang diperoleh dari penelitian ini adalah validitas modul berbasis Cooperative Type Student Facilitator And Explaining dinyatakan valid pada aspek materi didalam modul dengan total nilai validitas adalah 99,3\% dan pada aspek format modul dinyatakan valid dengan total nilai 91,7. Modul Cooperative Learning Tipe Student Facilitator dinyatakan praktis berdasarkan penilaian guru dengan nilai praktisitas 88,62 $\%$ dengan kategori sangat praktis dan $88,98 \%$ dengan kategori sangat praktis. Nilai efektivitas modul terlihat peningkatan nilai pretes 55,00 menjadi nilai 84,58 nilai postes
\end{abstract} dengan nilai gain score pada kategori sedang. \%. Berdasarkan temuan penelitian ini disimpulkan bahwa modul berbasis Cooperative Type Student Facilitator And Explaining valid, praktis, dan efektif untuk dimanfaatkan sebagai media pembelajaran pada mata pelajaran Estimasi Biaya Konstruksi.

\begin{abstract}
A B S T R A C T
Low understanding of students impacts low student learning outcomes in subjects due to teacher-centered learning orientation. Students have not been able to learn independently and only rely on material explanations from the teacher. Available teaching materials have not been able to facilitate students to learn independently and thoroughly. This research aims to analyze the effectiveness of the cooperative learning module student facilitator and explain. The research used to research and development methods using the Four-D (4D) development model. The data collection methods used were questionnaires and tests. The method of analysis was carried out by descriptive and inferential analysis with the t-test. The results obtained from this study were the validity of the module based on cooperative type student facilitator, and explaining was declared valid on the material aspects in the module with a total validity score was $99.3 \%$, and the module format aspect was declared valid with a total score of 91.7. The student facilitator type of cooperative learning module is practically based on the teacher's assessment with a practical score of $88.62 \%$ in the very practical category and $88.98 \%$ in the very practical category. The module effectiveness score increases the pretest score of 55.00 to 84.58 in the post-test score with the gain score in the medium category. Based on the findings of this study, it is concluded that the module based on cooperative type student facilitator and explaining is valid, practical, and effective to be used as a learning medium in the subject of estimating construction costs
\end{abstract}

\section{Introduction}

Learning is a process of interaction between students and learning resources. Good learning provides opportunities for students to be active in exploring and building their knowledge. Such learning will make students get more learning experiences, and of course, learning will be more meaningful. Meaningful learning 
will be generated if students gain experience and develop emotional intelligence, and the learning process is carried out with a constructive approach (Angela, 2014; Kostiainen et al., 2018). Realizing this is not an easy thing. It takes hard work from the teacher to create conducive learning. One of the factors that influence the learning process is teaching materials, for example, the learning module (Mukaromah, 2018; Pratiwi et al., 2017). The learning module is one of the concepts of teaching materials packaged systematically and comprehensively that contains learning experiences that are planned and designed to help students learn (Imansari \& Sunaryantiningsih, 2017; Kurniawan, 2019; Samsu et al., 2020). A module in the learning process will allow students to study independently (Andrinata et al., 2016; Setyadi \& Saefudin, 2019). A module in the learning process also provides opportunities for students to work together with their peers (Junaida et al., 2016). And the existence of a learning module will make students learn difficult material (Nurmeidina et al., 2020). So, the existence of a module in the learning process will greatly help the learning process. Therefore the teacher should do a module that students in the learning process can use.

However, the reality in the field is very different from what it should be, where teachers experience a shortage of time to deliver all material, especially in the semester where industrial practices are applied. It resulted in not all of the material being conveyed in-depth and even missed (Rhosyida \& Jailani, 2014). There is still a lack of teaching materials in learning modules (Rahmawati, 2015). The learning materials have not optimally studied various problems in learning assessment in Senior High Schools, and there are no specific modules available (Pratiwi et al., 2017). Even though the module has been used, it is still in the form of a textbook. A module like this is still considered less attractive to students (Khoirudin, 2016). Based on these descriptions, these problems can result in low learning outcomes. It is in line with the documentation that student learning outcomes during the 2018/2019 and 2019/2020 academic years have not shown encouraging results where on average, $50 \%$ of students have not shown completeness in learning. Some of the causes are dense material with short time and a teacher-centered learning approach, limited learning resources in printed books containing material based on existing basic competencies, causing teachers to take an important role in delivering learning material. Students who depend on the material presented by the teacher result in a lack of student activity in learning. If this is allowed, it will not have a good impact on learning outcomes and the quality of learning. Therefore we need a solution, the learning module.

The learning module is a medium for independent learning because it is equipped with independent study instructions (Susilo et al., 2016). Learning modules are more specific than textbooks. The learning module is one of the concepts of teaching materials packaged systematically and comprehensively that contains learning experiences that are planned and designed to help students learn (Imansari \& Sunaryantiningsih, 2017; Kurniawan, 2019; Samsu et al., 2020). A module in the learning process will allow students to study independently (Andrinata et al., 2016; Setyadi \& Saefudin, 2019). A module in the learning process also provides opportunities for students to work together with their peers (Junaida et al., 2016). And the existence of a learning module will make students learn difficult material (Nurmeidina et al., 2020). The advantages of this learning module are the reason some researchers have developed learning modules.

Several module development studies have been carried out. Research conducted by Faidah et al., (2019) found that the mathematics module based on Howard Gardner's Theory of Multiple Intelligences Using the Realistic Mathematics Education (RME) approach on the material cubes and blocks that have been developed is feasible to use. Research conducted by Ariana et al., (2020) found that the Discovery LearningBased module that has been developed is feasible to be used in the learning process and effectively improves the scientific literacy skills of Senior High School students. Research Mardiana et al., (2016) argued that the PBMassisted KRPL program module was significantly different from the PBL model class or the conventional class from the cognitive learning outcomes and environmental care attitudes. Research conducted by Oktaviani et al., (2020) argued that the integrated chemistry module STEM (Science, Technology, Engineering, and Mathematics) and PBL (Problem-Based Learning) are valid and effective to use. Research conducted by Hasanah et al., (2018) found that the physics module based on project-based learning on temperature and heat material was feasible. The physics module could effectively improve students' science process skills and critical thinking skills. So, the existence of a learning module based on an innovative learning model positively affects learning outcomes. This reason is one reason for developing the Cooperative Learning Type Student Facilitator and Explaining learning module.

This module was developed based on the Cooperative Learning Type Student Facilitator and Explaining. Cooperative Learning Student Facilitator and Explaining student facilitator and explaining is a learning model that allows students to solve mathematical problems. Students can also explain the material they have understood to other students (Mulyani, 2016; Panjaitan et al., 2019). This learning model provides opportunities for students to be more active in the learning process, and students are more able to work together and interact with their peers and teachers (Wahyuddin \& Yusuf, 2020). The existence of this learning module will have a positive influence on students' abilities in the learning process. This study aims to analyze the effectiveness of the cooperative learning module Student Facilitator and Explaining. The existence of this 
module will help teachers in the learning process and help students be more active in the learning process in terms of learning outcomes, activity, and student collaboration with learning resources.

\section{Method}

The type of research used is development research known as Research \& Development (R\&D) with a 4D (Four-D) development model. The development process consists of 4 stages: 1. define; 2. design; 3. develop; 4. Disseminate. This determination stage was carried out to determine the basic problems needed in developing a learning module based on the Cooperative Type Student Facilitator and Explaining in Construction Cost Estimation Subjects. At this stage, analysis and analysis activities were carried out on students, concepts, tasks, and basic problems faced in learning. Design Stage. This stage aimed to prepare a learning module development design based on Cooperative Type Student Facilitator and Explaining in Construction Cost Estimation Subjects. There were several steps taken at this stage: media selection, format selection, and initial design. Development Stage. This stage aimed to produce products that are valid, practical, and tested to be effective. The disseminate stage was the final stage of the 4-D step. After being validated and tested for practicality and effectiveness in a particular class, a valid, practical, and effective Construction Cost Estimation learning module was obtained. After that, disseminate was carried out on a limited scale.

This study consisted of 3 material experts consisting of 1 Head of the Construction and Property Engineering Expertise Program and two Construction Cost Estimation subjects. Expert Validator Learning Module Format consisted of 2 FT UNP Postgraduate lecturers and 1 Linguist Validator from MAN 1 Tanah Datar, and five teachers of vocational subjects in construction and property engineering. The five teachers consisted of one Head of Construction and Property Engineering Expertise Program, two Construction Cost Estimation subjects, and two other productive subject teachers, and 15 students as trial subjects.

The data collection methods used in this study were questionnaires and tests. The questionnaire method used in the validity of the grid module used in making the learning module validation questionnaire refers to the module format and material. The questionnaire grid can be seen in the following table. Practicality questionnaires by teachers and students are used to obtain data related to the ease and practicality of the learning modules being developed. The module practicality questionnaire by the teacher contains the quality of the material used in the learning module based on Cooperative Type Student Facilitator and Explaining, the characteristics of the module as a learning resource, and the benefits of learning modules based on Cooperative Type Student Facilitator and Explaining. At the same time, the module practicality questionnaire by students contains the media aspects of the learning module and the benefits of the learning module. The practicality of the questionnaire for students and teachers can be seen in tables 2 and 3 below.

This effectiveness instrument is used to obtain data about the level of effectiveness of the learning module being developed, a valid and reliable learning outcome test. The learning outcome test is used to obtain the data needed to determine student success after participating in learning using the learning module in the Construction Cost Estimation Subject. The instrument used to measure learning outcomes is by using questions. After the instrument was made, 14 students of class XI DPIB of SMK Negeri 1 West Sumatra were tested to determine the validity, reliability, difficulty level, and item difference. The instrument's validity is the ability of a measuring instrument to measure what must be measured according to its standards. At the same time, reliability is the ability of a measuring instrument to provide consistent measurement results at different times and places and determine the respondent's understanding of the question items.

Table 1. Validity Of The Module Format And Material

\begin{tabular}{llll}
\hline No & Aspect & \multicolumn{1}{c}{ Assessment Indicators } \\
\hline \multirow{2}{*}{ Module format } & a) & Module format aspects \\
& \multirow{2}{*}{ Module material } & b) & Aspects of Language \\
& a) & Aspects of material quality \\
\end{tabular}

Table 2. Questionnaire Module Practicality By The Teacher

\begin{tabular}{cll}
\hline No. & Variable aspects of practicality & \multicolumn{1}{c}{ Indicator } \\
\hline 1. & Module & a. Easy to use \\
& b. Generating student interest \\
& c. Retention of material \\
& d. Save time and effort \\
& e. Teacher interpretation \\
\hline
\end{tabular}




\begin{tabular}{|c|c|c|}
\hline No. & Variable aspects of practicality & Indicator \\
\hline & & $\begin{array}{l}\text { f. Attractiveness } \\
\text { g. Material suitability } \\
\text { h. Independent learning tools }\end{array}$ \\
\hline
\end{tabular}

Table 3. Practicality Questionnaire By Students

\begin{tabular}{|c|c|c|}
\hline No & Practicality Aspects & Indicator \\
\hline 1. & Module & $\begin{array}{l}\text { a. Learning objectives } \\
\text { b. Interest to learn } \\
\text { c. Independent learning } \\
\text { d. Easy use } \\
\text { e. Conformity of concepts } \\
\text { f. The right language } \\
\text { g. Easy to understand sentences } \\
\text { h. Material suitability } \\
\text { i. Easy to understand material } \\
\text { j. Increase Motivation } \\
\text { k. Increase activity }\end{array}$ \\
\hline
\end{tabular}

Data from the validation results of the cooperative-based learning module Student Facilitator and Explaining for the subject of Cost Estimation of Personnel Construction in the form of material validation and format validation were analyzed using the following steps: 1) The validity questionnaire consists of 5 answer categories: $5=$ Strongly Agree, $4=$ Agree, $3=$ Simply Agree, $2=$ Disagree, $1=$ Strongly Disagree. 2 ) Adding up the scores of each validator for all indicators, 3) Entering statistical data into the Aiken's V formula. The results of Aiken's calculations range from 0 to 1 . The number 0.6 can be interpreted to have a high enough coefficient, so the $\mathrm{V}$ score is 0.6 and above are declared in the valid category. Analysis of the practicality of the Cost Estimation module for learning construction based on Cooperative Type Student Facilitator and Explaining. The practicality of the learning module based on the Cooperative Type Student Facilitator and Explaining in the power transfer system course is analyzed as follows: 1) Score answers with the following criteria: $1=$ Strongly disagree, 2 = Disagree, 3 = Enough Agree, 4 = Agree, $5=$ Strongly Agree. 2) Determine the average score obtained by adding up the scores obtained from many indicators. 3) Giving practical scores with criteria according to table 4 below.

Tabel 4. Kriteria Praktikalitas Modul

\begin{tabular}{lll}
\hline No. & Achievement Level & Category \\
\hline 1 & $81-100$ & Very Practical \\
2 & $61-80$ & Practical \\
3 & $41-60$ & Practical enough \\
4 & $21-40$ & Less Practical \\
5 & $0-20$ & Impractical \\
\hline
\end{tabular}

Source: Modified from (Sunarto \& Riduwan, 2015)

Analysis of the effectiveness of learning modules based on the Cooperative Type Student Facilitator and Explaining in Construction Cost Estimation subjects. Analysis of learning outcomes used to determine the learning completeness of each student in the Construction Cost Estimation Subject. Students are declared complete if they get learning outcomes above the Minimum Completeness Criteria. The minimum completeness criteria for Construction Cost Estimation subject was 75. A comparison of student learning outcomes before using the module and after using the module is carried out to determine the effectiveness of student learning outcomes. Data on learning outcomes is carried out before the research or use of modules (Pretest Data). The learning outcome data after the module used Post-test data. The comparison between student achievement and post-test will be a measure of the effectiveness of the modules used. The criteria for the effectiveness of the module are determined by the conditions shown in table 5 below.

Data from the pretest and post-test were analyzed using the paired data t-test formula. This analysis was used to determine the significant difference between the pretest and post-test results. Before the t-test analysis is carried out, the prerequisite analysis test is carried out, the normality analysis, to see whether the data is normal or not. The homogeneity analysis is used to determine whether the data variants are the same. The normality and homogeneity tests were carried out using SPSS 
Table 5. criteria for the level of effectiveness of the learning module

\begin{tabular}{lll}
\hline No. & Achievement Level \% & \multicolumn{1}{c}{ Category } \\
\hline 1 & $81 \%-100 \%$ & Very effective \\
2 & $61 \%-80 \%$ & Effective \\
3 & $41 \%-60 \%$ & Effective enough \\
4 & $2 \% 1-40 \%$ & Less effective \\
5 & $0 \%-20 \%$ & Ineffective \\
\hline
\end{tabular}

Source: (Sunarto \& Riduwan, 2015)

\section{Result and Discussion}

\section{The Validation Results Of The Learning Module}

The results obtained were the validation scores for the resulting product development. The results of the validation summarized from the assessed aspects of the learning module as shown in table 6 below:

Table 6. The results of the material expert validation

\begin{tabular}{cccc}
\hline No & Validator & Rating & Category \\
\hline 1 & First Validator & 0,940 & Valid \\
2 & Second Validator & 0,840 & Valid \\
3 & Third Validator & 0,900 & Valid \\
\hline & Average & $\mathbf{0 , 8 9 3}$ & $\mathbf{0 , 8 9 3}$ \\
\hline
\end{tabular}

The results of the analysis of the validity test to the learning module material experts obtained an average aspect of 0.893> 0.667, so the learning module is included in the Valid category. Expert validators for Learning Module Format are three validators consisting of two FT UNP Postgraduate lecturers and one Linguist Validator from MAN 1 Tanah Datar. Furthermore, expert formatting validation can be seen in Table 7 below.

Table 7. validation results from expert format

\begin{tabular}{cccc}
\hline No & Validator & Rating & Category \\
\hline 1 & First Validator & 0,987 & Valid \\
2 & Second Validator & 0,867 & Valid \\
3 & Third Validator & 0,896 & Valid \\
\hline & Average & $\mathbf{0 , 9 1 7}$ & Valid \\
\hline
\end{tabular}

The results of the analysis of the validity test to the learning module format experts obtained an average aspect of $0.917>0.667$, so the learning module is included in the Valid category.

\section{Practicality Test Of The Learning Module}

Practicality relates to the ease of use of the learning modules being developed. Practicality data were obtained through a questionnaire filled in by five construction and property engineering vocational subjects. The five teachers consist of one Head of the Construction and Property Engineering Expertise Program, two teachers for Construction Cost Estimation, and two other productive subjects. The results of the assessment of the practicality of the learning module are summarized in table 8 below:

Table 8. recapitulation of practicality

\begin{tabular}{ccccc}
\hline NO & Respondent's Name & Total & Maximum Score & The Achievement Level of The Respondents \\
\hline 1 & First practitioner & 60 & 65 & 92,31 \\
2 & Second practitioner & 59 & 65 & 90,77 \\
3 & Third practitioner & 55 & 65 & 84,62 \\
4 & Fourth practitioner & 59 & 65 & 90,77 \\
5 & Fifth practitioner & 55 & 65 & 84,62 \\
\hline \multicolumn{6}{c}{ Total Score } & $\mathbf{3 2 5}$ & $\mathbf{4 4 3 , 0 8}$ \\
\hline \multicolumn{6}{c}{ Average } & $\mathbf{6 5}$ & $\mathbf{8 8 , 6 2}$ \\
\hline
\end{tabular}


According to the lecturer, the analysis results obtained that the average practicality test of the learning module was obtained a percentage score of 92.5 with a very practical interpretation. The results of the assessment of the practicality of the learning module are summarized in table 9 below.

Table 9. Practicality recapitulation based on student responses

\begin{tabular}{clcc}
\hline No & Respondent & $(\boldsymbol{\%})$ Aspect & Aspect Category \\
\hline 1 & Eleventh Grade Student DPIB & 88,98 & very practical \\
\hline
\end{tabular}

Based on table 8 and table 9 , it is obtained that the average practicality test results of the learning module based on the acquisition of lecturer data is $88.62 \%$. Based on the acquisition of student data of $88.98 \%$, the learning module is included in the "Very Practical" category.

\section{The effectiveness of the learning module}

Classical completeness is seen from the number of students who complete by comparing the minimum completeness criteria set after using the learning module. The basis for determining the effectiveness of the learning module is if the percentage of students' classical completeness is greater or equal to $85 \%$, then the learning module is effectively used. On the contrary, the percentage of students' classical completeness is smaller, with $85 \%$ of the learning modules not effectively used. The following are the results of the student's average score presented in table 10 .

Table 10. The result of effectiveness analysis based on KKM

\begin{tabular}{|c|c|c|c|c|c|c|c|}
\hline \multirow{2}{*}{ No } & \multirow{2}{*}{ total students } & \multirow{2}{*}{$\begin{array}{l}\text { Maximum } \\
\text { Score }\end{array}$} & \multirow{2}{*}{$\begin{array}{l}\text { Minimum } \\
\text { Score }\end{array}$} & \multicolumn{4}{|c|}{ Range of score } \\
\hline & & & & $<75$ & $\%$ & $\geq 75$ & $\%$ \\
\hline 1 & 16 & 100 & 46,67 & 2 & 12,5 & 4 & 87,5 \\
\hline
\end{tabular}

Based on the analysis results described in the table above, the total number of students completed was 14 students $(87.5 \%)$. It shows that classical completeness has been achieved. It can be concluded that the learning module is effective when viewed from classical completeness in terms of differences in pretest and post-test results. The pretest results were obtained after the implementation of the preliminary tests on students. They were analyzed using the SPSS data processing application to determine the data distribution, the average score, and the standard deviation of the data obtained. The analysis results using SPSS obtained the following results: a) the average score was 54.99 , b) the highest score was 86.67, c) the lowest score was 20 , d) the standard deviation was 20.58. Posttest data obtained after being implemented after using the learning module to students were analyzed using the SPSS data processing application. The following results were obtained: a) the average score was $84.58 \mathrm{~b}$ ) the highest score was $100, \mathrm{c}$ ) the lowest score was $46,67, \mathrm{~d}$ ) the standard deviation was 13.70 .

The pretest and post-test data normality test analysis at a significance level of 0.050 , obtained a pretest data normality score of 0.621 , which can be seen in the asymp sig (2-tailed). Because the normality score is greater than the significance score $(0.621>0.05)$, the data is declared to be normally distributed. Furthermore, for the post-test score, the normality score of the post-test data was 0.296 , which can be seen in the asymp sig (2-tailed). Because the normality score is greater than the significance score $(0.296>0.05)$, the data is declared to be normally distributed. While the homogeneity test obtained the pretest and post-test significance scores of $0.202>0.050$, meaning that the pretest and post-test data had the same/homogeneous variance and could be continued with hypothesis testing. Hypothesis testing is done by analyzing paired t-test (paired sample test) using the SPSS program. If the significance score $<0.05$, the decision criterion is a significant difference in student learning outcomes before and after using the learning module. If the significance score $>0.05$, it is stated that there is no significant difference in student learning outcomes before and after using the learning module. Based on the tests carried out, a significance score of $0.00(0.00<0.05)$ was obtained, meaning significant differences in student learning outcomes before and after using the learning module. Based on the analysis results, it was found that the tcount was -9.539 with ttable of 2.583 , because tcount $<$ ttable $(-9.539<2.583)$, it was stated that there was an increase in learning outcomes between before and after the learning module was applied.

The results showed that the learning module developed was valid, practical, and effective. It cannot be separated from the modules being developed and the learning models used. Modules are developed following the characteristics and needs of students. A learning module will make students learn more independently because they require students to shape their learning experience. The learning module is a medium for independent learning because it is equipped with independent study instructions (Susilo et al., 2016). Learning modules are more specific than textbooks. The learning module is one of the concepts of teaching materials 
packaged systematically and comprehensively that contains learning experiences that are planned and designed to help students learn (Imansari \& Sunaryantiningsih, 2017; Kurniawan, 2019; Samsu et al., 2020). A module in the learning process will allow students to study independently (Andrinata et al., 2016; Setyadi \& Saefudin, 2019). A module in the learning process also provides opportunities for students to work together with their peers (Junaida et al., 2016). And the existence of a learning module will make students learn difficult material (Nurmeidina et al., 2020). Several module development studies have been carried out, among others, research conducted by Faidah et al., (2019) found that the mathematics module based on Howard Gardner's Theory of Multiple Intelligences Using the Realistic Mathematics Education (RME) approach on the material cubes and blocks that have been developed is feasible to use. Research conducted by Ariana et al., (2020) found that the Discovery Learning-Based module that has been developed is feasible to be used in the learning process and effectively improves the scientific literacy skills of Senior High School students. Research Mardiana et al., (2016) argued that the PBM-assisted KRPL program module was significantly different from the PBL model class or the conventional class from the cognitive learning outcomes and environmental care attitudes. Research conducted Oktaviani et al., (2020) argued that the integrated chemistry module STEM (Science, Technology, Engineering and Mathematics) and PBL (Problem-Based Learning) are valid and effective to use. Research conducted by Hasanah et al., (2018) found that the physics module based on project-based learning on temperature and heat material was feasible and the physics module could effectively improve students' science process skills and critical thinking skills.

In addition, the existence of a learning model will make students more active in the learning process. Cooperative Learning Student Facilitator and Explaining student facilitator and explaining is a learning model that allows students to solve mathematical problems. Students can also explain the material they have understood to other students (Mulyani, 2016; Panjaitan et al., 2019). This learning model provides opportunities for students to be more active in the learning process, and students are more able to work together and interact with their peers and teachers (Wahyuddin \& Yusuf, 2020). Student Facilitator and Explaining is a learning model that trains students to present their ideas or ideas to their friends (Kholisah \& Wakijo, 2019). With good interaction between students and their peers, it will be easier for students to learn. The peer method enhances learning by themselves, learners through experiences which are feedback from their friends (Gabriele et al., 2016). Peers help, guide, and support peers to build learning through interaction and collaboration (Andersen $\&$ Watkins, 2018). Learning that involves peers will reduce anxiety and stress. Being guided, assisted, and given feedback by peers will increase self-confidence (Han et al., 2015; Stone et al., 2013). So the existence of the Student Facilitator and Explaining type of cooperative learning module can improve student learning outcomes.

The Cooperative Learning-based Construction Cost Estimation learning module is effective and feasible to implement because it can improve student learning outcomes. One of the characteristics of a module as teaching material is the principle of independent learning. Independent learning is a way of active learning and participation to develop each individual's self that is not tied to teachers, lecturers, face-to-face meetings in class, the presence of school friends (Anis, 2017; Sobri, Nursaptini, \& Novitasari, 2020). In developing this module, pay attention to the characteristics of the module so that it makes it easier for students to understand the subject matter. The developed modules are arranged systematically and attractively, including material content, methods, and evaluation, which can be used independently to achieve the expected competencies. The developed module has clear objectives, contains learning material in small/specific activity units, making it easier to study it thoroughly. There are examples to support the clarity of the exposure to learning materials. Have practice questions and assignments to measure the level of student understanding, contextual, the material presented following the environment and conditions of students simple language to understand the messages conveyed in the module easily. There is a material summary that helps students review the subject matter in question. An assessment instrument is available so that each student can assess his or her abilities. The use of this module can make students learn independently to achieve their goals. This module is different from other modules, where this module is made with the Steps of the Student Facilitator and Explaining cooperative learning model. This learning module effectively improves student learning outcomes to be used as a solution in the learning process related to learning outcomes.

\section{Conclusion}

The cooperative learning module Student Facilitator and Explaining are valid, practical, and effective in the learning process. The existence of this module can make students more active in exploring and building their knowledge independently or in groups. The existence of this module can be used as a solution in overcoming learning problems related to learning outcomes. 


\section{References}

Andrinata, Sumarmi, \& I Komang Astina. (2016). Pengembangan Modul Geografi Pariwisata Berbasis Paket Wisata Pulau Lombok Sebagai Upaya Memupuk Rasa Cinta Tanah Air Pada Mahasiswa. Jurnal Pendidikan: Teori, Penelitian, Dan Pengembangan, 1(10), 1999-2003. www.solopos.com.

Angela, T. (2014). Challenges to Meaningful Learning in Social Studies - The Key Competences as an Opportunity to Students' Active Participation. Procedia - Social and Behavioral Sciences, 128, 192197. https://doi.org/10.1016/j.sbspro.2014.03.142.

Ariana, D., Situmorang, R. P., \& Krave, A. S. (2020). Pengembangan Modul Berbasis Discovery Learning Pada Materi Jaringan Tumbuhan Untuk Meningkatkan Kemampuan Literasi Sains Siswa Kelas Xi Ipa Sma. Jurnal Pendidikan Matematika Dan IPA, 11(1), 34. https://doi.org/10.26418/jpmipa.v11i1.31381.

Faidah, N., Masykur, R., Andriani, S., \& Lina Herlina. (2019). Realistic Mathematics Education ( Rme ) Sebagai Sebuah Pendekatan Pada Pengembangan Modul Matematika Berbasis Teori Multiple Intelligences Realistic Mathematics Education ( Rme ) As an Approach To Development of Mathematical Module Based on Multiple Intel. Indonesia Journal of Science and Mathematics Education, 02(3), 328-332. https://doi.org/https://doi.org/10.24042/ijsme.v2i3.4396.

Hasanah, I., Sarwanto, S., \& Masykuri, M. (2018). Pengembangan Modul Suhu dan Kalor Berbasis Project Based Learning untuk Meningkatkan Keterampilan Proses Sains dan Kemampuan Berpikir Kritis Siswa SMA/MA. Jurnal Pendidikan (Teori Dan Praktik), 3(1), 38. https://doi.org/10.26740/jp.v3n1.p38-44.

Imansari, N., \& Sunaryantiningsih, I. (2017). Pengaruh Penggunaan E-Modul Interaktif Terhadap Hasil Belajar Mahasiswa pada Materi Kesehatan dan Keselamatan Kerja. VOLT : Jurnal Ilmiah Pendidikan Teknik Elektro, 2(1), 11. https://doi.org/10.30870/volt.v2i1.1478.

Junaida, S., Kusdiyanti, H., \& Churiyah, M. (2016). Meningkatkan Percaya Diri dan Hasil Belajar Siswa melalui Pengembangan Modul Mata Pelajaran Memberikan Pelayanan kepada Pelanggan Berbasis Guided Inquiry Siti. Jurnal Pendidikan Bisnis Dan Manajemen, 2(1), $75-93$. http://journal2.um.ac.id/index.php/jpbm/article/view/1692/964.

Khoirudin, M. (2016). Pengembangan Modul Pembelajaran Ipa Biologi Berbasis Inkuiri Pada Materi Interaksi Antar Makhluk Hidup Dengan Lingkungannya. BIOEDUKASI (Jurnal Pendidikan Biologi), 7(2). https://doi.org/10.24127/bioedukasi.v7i2.611.

Kholisah, A. D., \& Wakijo. (2019). Pengaruh Penggunaan Model Cooperative Learning Tipe Student Facilitator and Explaining (SFE) Terhadap Hasil Belajar IPS Terpadu Siswa Kelas VII Negeri 7 Metro. Jurnal $\begin{array}{lllll}\text { Pendidikan Ekonomi } & \text { UM } & \text { Metro, } & 6(2), & 152-157 .\end{array}$ https://ojs.fkip.ummetro.ac.id/index.php/ekonomi/article/view/1702/1069.

Kostiainen, E., Ukskoski, T., Ruohotie-Lyhty, M., Kauppinen, M., Kainulainen, J., \& Mäkinen, T. (2018). Meaningful learning in teacher education. Teaching and Teacher Education, 71, 66-77. https://doi.org/10.1016/j.tate.2017.12.009.

Kurniawan, G. E. (2019). Pengembangan Modul Pembelajaran Berbasis Model Problem Solving Untuk Meningkatkan High Order Thinking Skill Pada Pelajaran Ipa Pokok Bahasan Fluida Statis Siswa Kelas Viii Smp N 7 Cirebon Tahun Ajaran 2018/2019. Mangifera Edu, 4(1), 63-72. https://doi.org/10.31943/mangiferaedu.v4i1.531.

Mardiana, Muhdhar, M. H. I. Al, \& Sueb. (2016). Pengaruh Modul Program KRPL Berbantuan Pembelajaran Berbasis Msalah (PBM) Terhadap Hasil Belajar Kognitif Dan Sikap Peduli Lingkungan Siswa Kelas VII SMPN 18 Malang. Teori, Penelitian, Dan Pengembangan, 1(1), $25-34$. http://journal.um.ac.id/index.php/jptpp/article/view/6604.

Mukaromah, S. M. (2018). Pengembangan Modul IPA Braille Berbasis Integrasi Islam dan Sains. Inklusi, 5(2), 195. https://doi.org/10.14421/ijds.050203.

Mulyani, E. (2016). Pengaruh penggunaan model pembelajaran kooperatif tipe student facilitator and explaining terhadap pemahaman matematik peserta didik. Jurnal Penelitian Pendidikan Dan Pengajaran Matematika, 2(1), 29-34. http://jurnal.unsil.ac.id/index.php/jp3m/article/view/Eva21.

Nurmeidina, R., Lazwardi, A., \& Ariyanti, I. (2020). Pengembangan Modul Teori Peluang Untuk Meningkatkan Hasil Belajar Dan Disposisi Matematis. AKSIOMA: Jurnal Program Studi Pendidikan Matematika, 9(2), 440-450. https://doi.org/10.24127/ajpm.v9i2.2824.

Oktaviani, A., Anom, K., \& Lesmini, B. (2020). Pengembangan Modul Kimia terintegrasi STEM (Science, Technology, Engineering and Mathematics) dan PBL (Problem-Based Learning). Journal of Educational Chemistry (JEC), 2(2), 64. https://doi.org/10.21580/jec.2020.2.2.6279.

Panjaitan, K., N., L., \& Guslinda. (2019). Penerapan Model Pembelajaran Kooperatif Tipe Student Facilitator and Explaning untuk Meningkatkan Hasil Belajar IPS Kelas III SDN 192 Pekanbaru. Jurnal PAJAR $\begin{array}{lcr}\text { (Pendidikan Dan } & \text { Pengajaran), } \\ \text { http://jurnal.unsil.ac.id/index.php/jp3m/article/view/Eva21. }\end{array}$ 
Pratiwi, P. H., Nur, H., \& Martiana, A. (2017). Pengembangan Modul Mata Kuliah Penilaian Pembelajaran Sosiologi Berorientasi Hots. Jurnal Cakrawala Pendidikan, 36(2), 201-209. https://doi.org/https://doi.org/10.21831/cp.v36i2.13123.

Rahmawati, A. (2015). Pengembangan Modul Kimia Dasar Berbasis Multipel Level Representasi untuk Meningkatkan Kemampuan Berpikir Kritis Mahasiswa. Phenomenon: Jurnal Pendidikan MIPA, 5(2), 5-17. https://journal.walisongo.ac.id/index.php/Phenomenon/article/view/76.

Rhosyida, N., \& Jailani, J. (2014). Pengembangan Modul Matematika Smk Bidang Seni, Kerajinan, Dan Pariwisata Berbasis Open-Ended Problem Sebagai Implementasi Ktsp. Jurnal Riset Pendidikan Matematika, 1(1), 35. https://doi.org/10.21831/jrpm.v1i1.2662..

Samsu, N., Mustika, D., Nafaida, R., \& Manurung, N. (2020). Analisis Kelayakan dan Kepraktisan Modul Praktikum Berbasis Literasi Sains untuk Pembelajaran IPA. Jurnal IPA \& Pembelajaran IPA, 4(1), 2940. https://doi.org/10.24815/jipi.v4i1.15546.

Setyadi, A., \& Saefudin, A. A. (2019). Pengembangan modul matematika dengan model pembelajaran berbasis masalah untuk siswa kelas VII SMP. Pythagoras: Jurnal Pendidikan Matematika, 14(1), 12-22. https://doi.org/10.21831/pg.v14i1.16771.

Sunarto, \& Riduwan. (2015). Pengantar Statistik. Bandung: Alfabeta.

Susilo, A., Siswandari, \& Bandi. (2016). Pengembangan modul berbasis pembelajaran saintifik untuk peningkatan kemampuan mencipta siswa dalam proses pembelajaran akuntansi siswa kelas XII SMAN 1 Slogohimo 2014. Jurnal Pendidikan Ilmu Sosial, 26(1), 50-56. http://journals.ums.ac.id/index.php/jpis/article/viewFile/2127/1567.

Wahyuddin, W., \& Yusuf, I. W. (2020). Efektivitas Pembelajaran Matematika Melalui Penerapan Model Kooperatif Tipe Student Facilitator and Explaining. JPMI (Jurnal Pendidikan Matematika Indonesia), 5(1), 16. https://doi.org/10.26737/jpmi.v5i1.1369. 